\title{
TOPOGRAPHICAL CHARACTERISTICS USED BY SOUTHERN GIANT PETREL Macronectes giganteus AT STINKER POINT, ELEPHANT ISLAND
}

http://dx.doi.org/10.4322/apa.2014.030

Maria Virginia Petry ${ }^{1, *}$, Lucas Krüger ${ }^{1}$, Rafael Gomes de Moura ${ }^{1}$

${ }^{1}$ Laboratório de Ornitologia e Animais Marinhos - LOAM, Universidade do Vale do Rio dos Sinos - UNISINOS, São Leopoldo, Rio Grande do Sul, Brazil

*e-mail: vpetry@unisinos.br

Abstract: The choice of breeding site is important for a seabird with consequences on the successful raising of its chicks. Seabirds may choose a breeding site taking into account many environmental and biological factors. This study aims to test the association of Southern Giant Petrel nests with topographical parametersat Stinker Point, Elephant Island. 33 Southern Giant Petrel nests were identified using a GPS receptor, and generated 33 random points. The points were plotted on a raster DEM and variables were extracted. We verified the nests were associated with terrain slope and altitude, and that Petrels were using the intermediary elevations (below $90 \mathrm{~m}$ ) in plain terrains at Stinker Point. As there are also other variables that can influence habitat use, further analysis is needed to establish the exact role of topography on nesting habitat selection.

Keywords: digital elevation model, habitat selection, habitat use, nesting

\section{Introduction}

Habitat selection is a hierarchical process of behavioural responses that result in the disproportional use of one or few habitat attributes in relation to others, such differences in use may positively affect the breeding success (Jones, 2001). Decisions on which habitat is preferable for a bird are influenced by many parameters of the chosen location itself and by parameters of the populations and communities occupying them, habitat includes as broad parameters as size, quality, structure, accessibility, resource availability and so on, while population and communities impose that birds make choices to avoid competition and predation (Guthrie \& Moorhead, 2002). For a seabird, the choice of nesting ground plays a fundamental role on the reproductive success, most species breed in colonies with a hundred to a thousand individuals, but the only resource for wich they compete in colonies is area. Choosing a good place for nesting implies in occupying places protected from wind, snow, from excessive or insufficient insulation, and protection from predators (Danchin \& Wagner, 1997). Birds may use the information of conspecific success for choosing their own nesting site, it is, the presence of an experienced breeder in one site is the indicative that this site can provide suitable habitat for reproduction (Forbes \& Kaiser, 1994), so, thus, enhancing the importance of local characteristics from the analytical point of view. The objective of the present paper is to evaluate topographical characteristics to which Southern Giant Petrels are nest-associated at Stinker Point, Elephant Island, in an attempt to understand factors explaining colony distribution.

\section{Materials and Methods}

The study was conducted at Stinker Point, Elephant Island, South Shetland Island on the austral summer of 2009/2010. At Stinker point there are two main colonies of Southern 
Giant Petrel (SGP), and during this season 931 breeding pairs were counted. We accompanied 33 nests of SGP which adults were incubating in December 2009. We marked the georreferences of the 33 nests with a GPS receptor. Random points were generated through random function using Microsoft Office Excel 2007. The random points were used for accessing the entire variation of topography a priori available to birds. A Digital Elevation Model (DEM) was elaborated from an altimetry satellite image through ArcGis Software (Figure 1). The DEM allowed us to extract the following topographical parameters: Elevation (meters), Slope (terrain inclination), and Aspect (direction of terrain inclination). To evaluate the association of nests with the topographical parameters we used Principal Component Analysis.

\section{Results}

The SGPs nested at Stinker Point in areas from 13 to 86 metres above sea level with terrain face directed from South $\left(180^{\circ}\right)$ to Southwest $\left(240^{\circ}\right)$ and Slope variation between $0.006^{\circ}$ and $0.021^{\circ}$ (Table 1). The Principal Component Analysis resulted in three components (Table 2), both Component 1 and Component 2 explained $76 \%$ of data variance. Component 1 is explained by Elevation and Slope, while Component 2 is explained by Aspect (Table 3). The PCA shows that the SGPs were breeding in a habitat that was a fraction of the potentially available area at Stinker Point, that is, the nests represented only a small group in the middle of the random points (Figure 2).

Two distinct groups existed within the nests, however, one occupied the South face (negative association

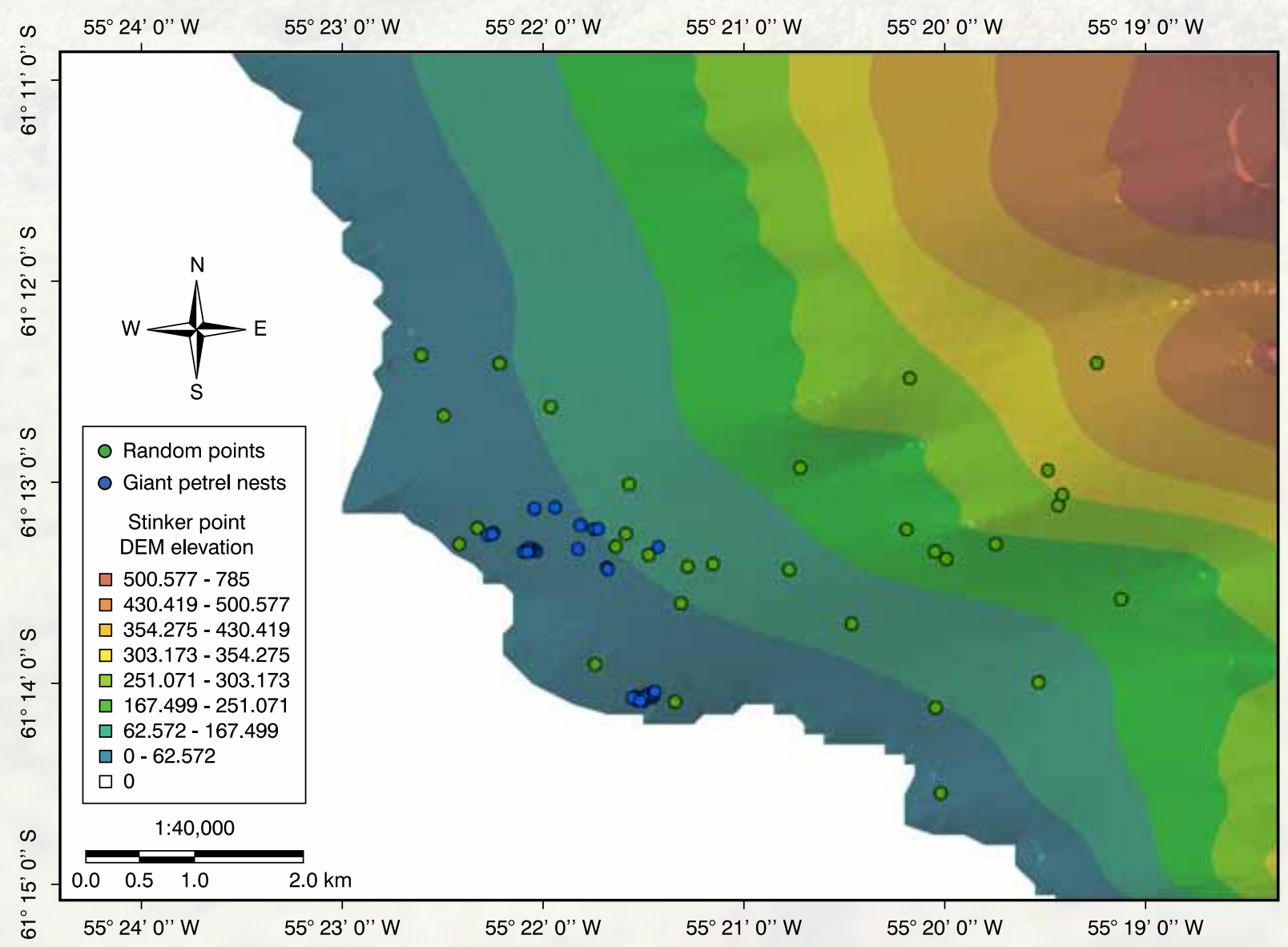

Figure 1. Stinker Point DEM, Elephant Island, classified in elevation intervals, with sampling points plotted. 
Table 1. Descriptive Statistics of Topographical parameters

\begin{tabular}{|c|c|c|c|c|c|}
\hline Parameters & Range & Minimum & Maximum & Mean & Std. Deviation \\
\hline Elevation (m) & 72.40 & 13.77 & 86.17 & 45.38 & 18.96 \\
\hline Slope $\left({ }^{\circ}\right)$ & 0.02 & 0.006 & 0.021 & 0.013 & 0.01 \\
\hline Aspect $\left({ }^{\circ}\right)$ & 59.04 & 180.00 & 239.04 & 209.78 & 23.02 \\
\hline
\end{tabular}

Table 2. Eigenvalue and percentage of variance explained by the three Principal Components (PC)

\begin{tabular}{ccc|}
\hline PC & Eigenvalue & $\%$ \\
1 & 1.26 & 42.06 \\
2 & 1.03 & 34.18 \\
3 & 0.71 & 23.75 \\
\hline
\end{tabular}

Table 3. Correlation of each topographical variable with the Principal Components.

\begin{tabular}{cccc} 
Variable & PC1 & PC2 & PC3 \\
Aspect & -0.14 & 0.96 & 0.26 \\
Elevation & 0.81 & -0.13 & 0.58 \\
Slope & 0.77 & 0.31 & -0.56 \\
\hline
\end{tabular}

with Component 2), and the other Southwest (positive association with Component 2). Component 1 revealed that both groups were established at lower Elevations and Lower Slopes, however, South groups tended to occur in small numbers athigh elevations and ata fewer number of the smaller slopes than the Southwest group (Figure 2).

\section{Discussion}

Southern Giant Petrels seems to be adapted to nest at a very specific habitat in Stinker Point, at Elevations below $90 \mathrm{~m}$ on almost flat terrains. The direction to which these flat areas were pointed (Aspect) was not selected by the SGPs, it seemedonly to be a consequence of the topography selected by SGPs than for any other reason, while Elevation and Slope played a more explicit role in influencing nest position at Stinker Point. However, there were a lot of other

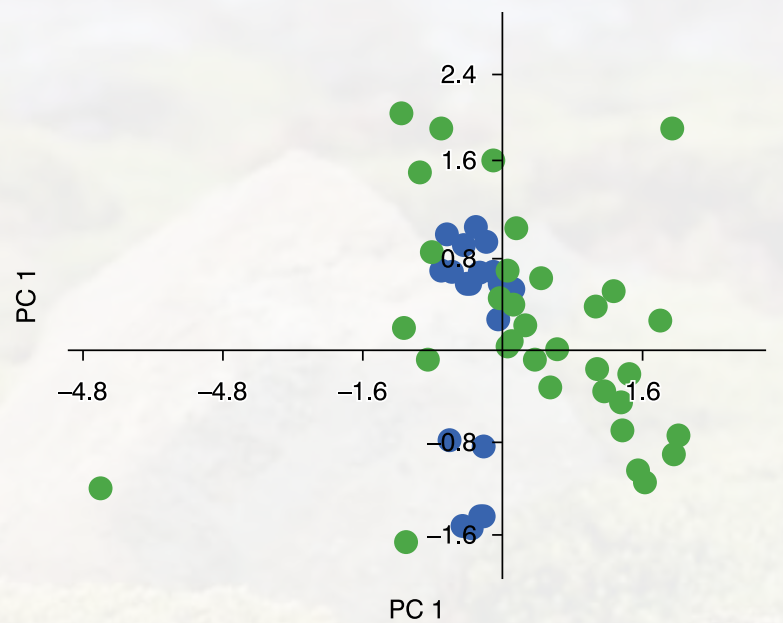

Figure 2. Principal Components plot with the two first components explaining $76 \%$ of the data variation. Blue circles are the Southern Giant Petrel nests, and green circles are the random points. Component 1 is explained by Elevation and Slope, while Component 2 is explained by Aspect.

non-measured factors that could contribute to the presence of seabird colonies in a given place, such as solar incidence, wind exposure, ice-free land, distance from predators (Brown Skuas in Stinker Point), inter- and intra-specific competition, density and parasites (Rönkä et al., 2008). Potentially, there are others places where a colony was expected to be seen, mainly areas of Glacier retraction (MVP pers. comm.), which could be placed among those specific reliefs used by SGP. One explanation is social attraction (Danchin et al., 1998; Parejo et al., 2006), that is, the previous observation of conspecific success being indicative of site quality for breeding. In other words, where one experienced bird chose to breed would probably be a good location, hence younger birds and first breeders would tend to use such places through this socially available information. 


\section{Conclusion}

More profound analyses are still needed to understand the observed trend. GIS is a very useful tool for the development of models for explaining the colonies distribution. Incorporating a wide range of topographic, abiotic and biotic information can cause the emergence of a coherent understanding of why SGPs at Stinker Point are using flat areas below $90 \mathrm{~m}$ from sea level, and if there is any effect of those characteristics on fitness, so they can be seen as true Habitat Selection parameters.

\section{Acknowledgements}

Brazilian data was provided through projects financed by INCT-APA (CNPq Process no. 574018/2008-5, FAPERJ E-26/170.023/2008)], and supported by the Ministry of Environment, Ministry of Science and Technology, and the Secretariat for the Marine Resources Interministerial Committee (SECIRM).

\section{References}

Danchin, E. \& Wagner, R. (1997). The evolution of coloniality: the emergence of new perspectives. Trends in Ecology and Evolution, 12:342-7

Danchin, E., Boulinier, T. \& Massot, M. (1998). Conspecific reproductive success and breeding habitat selection: implications for the study of coloniality. Ecology 79(7): 2415-28.

Forbes, L.S. \& Kaiser, G.W. (1994). Habitat choice in breeding seabirds: when to cross the information barrier. Oikos, 70: $377-84$.

Guthrie, C.G. \& Moorhead, D.L. (2002). Density-dependent habitat selection: evaluating isoleg theory with a Lotka-Volterra model. Oikos, 97:184-94.

Jones, J. (2001). Habitat selection studies in avian ecology: a critical review. The Auk, 118(2): 557-62.

Parejo, D., Oro, D. \& Danchin, E. (2006). Testing habitat copying in breeding habitat selection in a species adapted to variable environments. Ibis, 148: 146-54.

Rönkä, M., Tolvanen, H., Lehikoinen, E., Numers, M. \& Rautkari, M. (2008) Breeding habitat preferences of 15 bird species on South-western Finnish archipelago coast: applicability of digital spatial data archives to habitat assessment. Biological Conservation, 141:402-16. 